\title{
EKOFEMINISME : KONSTRUKSI SOSIAL BUDAYA PERILAKU PEREMPUAN DALAM PENGELOLAAN LINGKUNGAN HIDUP
}

\author{
${ }^{1}$ Novita Sari, ${ }^{2}$ Rabina Yunus, ${ }^{3}$ Suparman \\ 1Mahasiswa Pascasarjana Sosiaologi Universitas Hasanuddin \\ 2 Guru Besar Ilmu Pemerintahan Universitas Hasanuddin \\ 3 Dosen Pascasarjana Sosiologi Universitas Hasanuddin \\ Jl. Perintis Kemerdekaan KM.10, Tamalanrea Indah, Kec. Tamalanrea \\ E-mail: 102novitasari02@gmail.com,2 rabina yunus@yahoo.com,33mansosio87@yahoo.com
}

\begin{abstract}
The culture of patriarchy is the root of the oppression of women and nature. Patriarchal culture has a big contribution in shaping women's behavior in environmental management. This study aims to conduct precision analysis of how socio-cultural construction of women's behavior in environmental management. The method used in this study is qualitative with a case study approach. The results showed that women's behavior in environmental management on Bontosua Island was a result of social construction through three dimensions, namely externalization was an activity carried out by women in natural management such as dumping garbage in the sea, burning plastic waste, reusing used plastic bottles, planting trees, reducing the use of non-environmentally friendly products. Objectivation is the process of women starting to pay attention to feedback from their external activities such as throwing garbage into the sea is not something wrong because they do not get a direct impact on these activities. Internalization is that women start accepting, settling and repeating their behavio r in managing the environment. From the sociological analysis, it can be seen that the behavior of women in environmental management on Bontosua Island tends not to be proactive due to the social construction process which does not really pay attention to environmental issues.
\end{abstract}

Keywords: Women, Environment, Social Construction

\begin{abstract}
Abstrak
Budaya patriarki menjadi akar dari tejadinya opresi terhadap perempuan dan alam. Budaya patriarki memiliki andil besar dalam pembentukan perilaku perempuan dalam pengelolaan lingkungan hidup. Penelitian ini bertujuan untuk melakukan presisi analisis tentang bagaimana konstruksi sosial budaya terhadap perilaku perempuan dalam pengelolaan lingkungan hidup. Metode yang digunakan dalam penelitian ini adalah kualitatif dengan pendekatan studi kasus. Hasil penelitian menunjukkan bahwa perilaku perempuan dalam pengelolaan lingkungan hidup di pulau Bontosua merupakan hasil dari konstruksi sosial yang melalui tiga dimensi yaitu eksternalisasi merupakan aktivitas yang dilakukan perempuan dalam pengelolaan alam seperti membuang sampah di laut, membakar sampah plastik, menggunakan ulang botol plastik bekas, menanam pohon, mengurangi penggunanaan produk tidak ramah lingkungan. Obyektivasi merupakan proses perempuan mulai memperhatikan feedback dari aktivitas eksternalnya misalnya membuang sampah ke laut bukanlah sesuatu yang salah karena mereka tidak mendapatkan dampak langsung dari aktivitasnya tersebut. Internalisasi yaitu perempuan mulai menerima, mengendapkan serta mengulang-ulang perilakunya dalam pengelolaan lingkungan hidup. Dari analisis sosiologis tersebut, terlihat
\end{abstract}


bahwa perilaku perempuan dalam pengelolaan lingkungan di pulau Bontosua cenderung tidak proaktif dikarenakan proses konstruksi sosialnya yang memang kurang memperhatikan isu lingkungan.

Kata Kunci,: Perempuan, Lingkungan Hidup, Konstruksi Sosial

\section{PENDAHULUAN}

Diskursus tentang manusia dan lingkungan hidup menjadi suatu hal yang penting untuk dielaborasi, bukan hanya dalam ilmu alam tapi juga dalam ilmu sosial, mengingat masalah sosial memiliki keterkaitan dengan masalah lingkungan hidup secara ekologis. Dimana salah satu sebab adanya masalah sosial berakar dari masalah ekologis, begitupun sebaliknya. Masalah ekologis yang terjadi dipicu oleh adanya masalah sosial. Bookchin berpendapat bahwa ekologi sebagai sosial adalah pengakuan terhadap fakta yang terlih at bahwa semua permasalahan ekologi kita saat ini berasal dari permasalahan sosial yang telah mengakar dalam. Permasalahan ekologi saat ini tidak bisa dipahami dengan jelas, apalagi hanya dipecahkan tanpa berurusan pada masalah dalam masyarakat. Konflik ekonomi, etnis, budaya dan gender, diantara banyak hal lainnya, intinya terletak pada dislokasi ekologis dan bencana alam yang diakibatkannya. ${ }^{1}$

Ditinjau secara historis antropologis, interaksi manusia dengan alam telah menciptakan kebudayaan. Dengan kecerdasannya, manusia memanfaatkan alam lingkungannya untuk pemenuhan kebutuhan hidupnya. Pada zaman nenek moyang, alam dimanfaatkan hanya sekadar untuk pemenuhan kebutuhan hidup. Seiring berjalannya waktu, pengetahuan manusia semakin maju dan mulai menciptakan teknologi-teknologi untuk membantu atau mempermudah pemenuhan kebutuhan hidupnya. Ilmu pengetahuan modern secara evolutif ternyata ikut mengubah karakter manusia. Manusia yang awalnya memanfaatkan alam demi keberlangsungan hidupnya, kini telah bergeser karena terhegemoni oleh kepentingankepentingan kapitalis yang notabenenya menjadi produk dari pekembangan ilmu pengetahuan modern. Akibatnya, mewabahlah antroposentrisme dimana alam dijadikan objek dan manusia menjadi subjek yang akan mengeksploitasi alam seenaknya saja.

Yuval Noah Harari dalam bukunya Sapiens berpendapat bahwa manusia mengalami tiga revolusi yang juga berpengaruh terhadap relasi antara manusia dengan lingkungan hidupnya. Revolusi tersebut adalah revolusi kognitif, revolusi pertanian dan revolusi sains. ${ }^{2}$ Revolusi kognitif adalah kondisi dimana nenek moyang manusia yang diistilahkan dengan pemburu-pengumpul telah mulai mengenal tentang cara pemanfaatan lingkungan alam untuk pemenuhan kebutuhan, mulai mengenal tentang mitos keberadaan dewa-dewa, hak asasi manusia, kemerdekaan, kesetaraan,

\footnotetext{
${ }^{1}$ Bookchin, Murray. 2018. Ekologi dan Anarkisme: Kumpulan Esai, diterjemahkan oleh Bima Satria Putra. Yogyakarta: Pustaka Catut

2 Harari, Youval Noah. 2017. Sapiens, Riwayat Singkat Umat Manusia. Diterjemahkan oleh Damari Tyas Wulandari Palar dari edisi berbahasa Inggris berjudul Sapiens, 2014. Jakarta: Kepustakaan Populer Gramedia.
} 
kapitalisme, feminisme dan lain-lain. Manusia pada revolusi ini juga telah mengetahui konsekuensi pemanfaatan lingkungan alam..

Pada revolusi pertanian, manusia perlahan meninggalkan kegiatan berburu dan mulai bercocoktanam serta mengenal teknik-teknik bertani. Selain itu, manusia juga mulai beternak dan membangun desa sebagai tempat tinggal menetapnya. Pada revolusi sains, Harari menyebut revolusi ini bisa menjadi awal kebangkitan manusia pun sebaliknya, bisa jadi menjadi kehancuran manusia. Revolusi sains menghadirkan pondasi-pondasi kapitalis. Sebuah gagasan yang awalnya bersifat pemenuhan kebutuhan namun dalam perjalanannya membentuk mental-mental eksploitatif karena terhegemoni oleh kepentingan-kepentingan ekonomi.

Faktor yang menyebabkan terjadinya kerusakan lingkungan salah satunya yaitu adanya pergeseran pandangan hidup manusia dari ekosentris menjadi antroposentris. Penganut paham antroposentrik memperlakukan alam sebagai objek pemenuh kebutuhannya. Pandangan hidup tersebut bermuara pada terjadinya eksploitasi sumber daya alam, akibatnya terjadilah deplesi sumberdaya dan rusaknya fungsi ekologi hidup manusia. Untuk mendapatkan gambaran jelas tentang proses pergeseran sudut pandang manusia terhadap alam, kita bisa menilik gagasan salah satu sosiolog dari Prancis, Auguste Comte tentang tiga tahap perkembangan akal budi manusia. Comte menjelaskan tiga tahapan perkembangan intelengensi manusia yaitu tahap teologi, tahap metafisik atau abstrak dan tahap positivistik atau ilmiah.

Tahap teologi, sistem ide utama menekankan kepercayaan bahwa akar segala sesuatu adalah kekuatan-kekuatan supernatural dan tokoh-tokoh agamais yang diteladani oleh manusia. Tahap metafisik, ditandai oleh kepercayaan pada dayadaya abstrak alam, bukanlah dewa-dewa yang berkepribadi, yang menjelaskan hampir segala sesuatu. Dan pada tahap positivistic, manusia cenderung membuang pencarian sebab-sebab absolut (Tuhan atau alam) dan sebagai gantinya memusatkan perhatian pada pengamatan dunia sosial dan fisik untuk mencari hukum-hukum yang mengaturnya. ${ }^{3}$ Tiga tahap perkembangan akal budi masyarakat dari Comte, dapat dilihat bahwa pada tahap teologi dan metafisik, manusia masih memiliki ketergantungan yang kental terhadap alam jadi manusia masih memperlakukan alam laiknya partner hidup dan menjunjung tinggi etika terhadap lingkungan alam. Namun pada tahap positivistik, manusia sudah mulai merasa bahwa alam diciptakan untuk manusia dan eksploitasipun dimulai serta perlahan melupakan etika-etika lingkungan.

Perjalanan panjang hubungan manusia dengan lingkungan hidupnya yang terus berkembang dan melahirkan berbagai perspektif tentang etika terhadap lingkungan, melahirkan varian baru yang menggabungkan alam dengan perspektif gender yang kemudian disebut ekofeminisme. perempuan selalu terkait erat dengan lingkungan dan pengelolaan lingkungan. Perempuan bergaul akrab dengan produk-produk yang berdampak pada

limbah dan pencemaran lingkungan. Misalnya limbah rumah tangga, dampak pemakaian kosmetik dan limbahnya, pemakaian obat kimiawi baik makanan

\footnotetext{
3 Ritzer, George. 2012. Teori Sosiologi, dari sosiologi klasik sampai perkembangan terakhir postmodern (edisi kedelapan). Yogyakarta: Pustaka Pelajar
}

Vol 3, No.2, Oktober 2019 
maupun kesehatan, pemakaian produk fashion, termasuk suplemen untuk body language pembentukan tubuh yang langsing, obat-abatan diet dan lain-lain. Dengan demikian perempuan mempunyai peran sentral dan strategis dalam pengelolaan lingkungan. ${ }^{4}$

Ketika hal tersebut ditinjau secara sosiologis, ekofeminisme merupakan sebuah realitas sosial yang dibentuk oleh adanya proses sosial. Proses dialektik dalam masyarakat terdiri dari tiga momentum yaitu eksternalisasi, obyektivasi dan internalisasi. Melalui eksternalisasi, masyarakat merupakan produk manusia. Melalui obyektivasi, masyarakat merupakan realitas yang unik. Melalui internalis asi, manusia merupakan produk masyarakat. Dalam teori konstruksi sosial ditegaskan bahwa masyarakat yang hidup dalam konteks sosial tertentu akan melakukan proses interaksi secara simultan dengan lingkungan hidupnya. Masyarakat hidup dalam dimensi realitas objektif yang dikonstruk melalui proses eksternalisasi dan obyektivasi, dan dimensi realitas subjektif yang dikonstruk melalui proses internalisasi. Jika disederhanakan, melalui proses obyektivasi dan internalisasi akan membentuk pengetahuan atau persepsi perempuan tentang lingkungan hidupnya dan melalui proses eksternalisasi akan melahirkan peranan perempuan dalam pengelolaan lingkungan hidupnya. Jadi kesimpulan sederhananya, adanya konstruksi sosial terhadap pembentukan pengetahuan dan peran perempuan dalam mengelola lingkungan hidupnya.

Hal tersebutjuga terjadi di Pulau Bontosua. Pulau Bontosua merupakan salah satu pulau kecil yang secara geografis masuk dalam wilayah Kabupaten Pangkajene dan Kepulauan. Luas Pulau Bontosua sekitar satu kilometer. Mayoritas laki-laki bekerja sebagai nelayan sedangkan perempuan mayoritas berprofesi sebagai ibu rumah tangga. Dari data tersebut, dapat dilihat bahwa perempuan memiliki waktu lebih banyak tinggal di pulau dibanding laki-laki, jadi peran perempuan sangatlah dibutuhkan dalam pengelolaan lingkungan di sekitar pulau.

Penelitian ini bertujuan untuk mengetahui bagaimana proses konstruksi sosial yang terjadi di pulau Bontosua terhadap perilaku para perempuan dalam pengelolaan lingkungan hidup di pulau Bontosua.

\section{METODE}

Penelitian ini menggunakan pendekatan kualitatif dengan metode study kasus (case study). Penelitian ini bertujuan untuk menggali informasi sebanyak mungkin tentang peran perempuan dalam pengelolaan lingkungan hidup. Peneliti memilih pendekatan kualitatif dengan metode study kasus karena peneliti ingin mengekplorasi secara mendalam mengenai aktivitas para perempuan dalam pengelolaan lingkungan hidupnya berdasarkan pengumpulan data yang ekstensif dan intensif. Study kasus dibedakan menjadi tiga macam yaitu study kasus history,

\footnotetext{
${ }^{4}$ Astuti, Tri Marhaeni Pudji. 2012. Ekofeminisme Dan Peran Perempuan Dalam Lingkungan. Indonesian Journal of Conservation Vol. 1 No. 1 - Juni 2012
} 
study kasus observasi dan study kasus biografi. ${ }^{5}$ Dalam penelitian ini, yang digunakan adalah pendekatan study kasus observasi yaitu kajian memprioritaskan observasi dan partisipasi sebagai teknik pengumpulan data artinya data yang diamati adalah data yang terjadi saatini. Untuk itu, peneliti harus ikut berpartisipasi dalam aktivitas yang diamati. Penelitian ini dilakukan dengan beberapa tahapan proses yakni observasi, indept interview, dan dokumentasi. Observasi atau pengamatan dilakukan terhadap objek atau subjek penelitian, tidak hanya pada awal penelitian akan tetapi juga selama peneelitian berlangsung. Menurut Poerwandari, observasi adalah tindakan yang dilakukan yang mengarah pada pengamatan secara akurat guna menemukan dan mencatat fenomena-fenomena yang dianggap penting, dan mempertimbangkan keterkaitan antar aspek dalam fenomena tersebut. ${ }^{6}$ Observasi dalam penelitian kualitatif ada berbagai bentuk. Dalam penelitian ini digunakan observasi partisipan. Observasi partisipan merupakan tindakan pengamatan yang dilakukan dengan cara mengikuti kegiatan kegiatan yang dilakukan oleh subjek penelitian dan pengamat menempatkan diri sebagai bagian dari subjek tersebut.7 Observasi dalam penelitian ini dilakukan tidak hanya pada tahap awal tapi sepanjang penelitian berlangsung. Observasi dilakukan karena merupakan bagian dari proses pengumpulan data, juga bermanfaat untuk memberikan perspektif tersendiri. Adapun aspek yang diobservasi yaitu kondisi lingkungan hidup pulau Bontosua dan kehidupan masyarakat pulau dalam pengelolaan lingkungan hidupnya. Wawancara mendalam dimaksudkan untuk mendapatkan informasi dari informan secara detil. Wawancara mendalam dilakukan secara langsung, hal ini dilakukan untuk memperoleh pandangan, sikap, dan pola pikir dari informan mengenai permasalahan yang diteliti. Wawancra mendalam disebut sebagai wawancara tidak terstruktur, wawancara kualitatif, wawancara intensif, dan wawancara terbuka (opened interview). Wawancara tidak terstruktur ini bersifat luwes, susunan-susunan pertanyaan dapat diubah pada saat wawancara, disesuaikan dengan kebutuhan-kebutuhan dan kondisi saat wawancara, termasuk karekteristik sosial budaya (agama, suku, gender, usia, tingkat pendidikan, pekerjaan, dsb). Berdasarkan sasaran penjawabnya, jenis wawancara yang dilakukan dalam penelitian ini adalah wawancara pero rangan dan tidak terstruktur. Berdasarkan pada pemilihan metode wawancara tak berstruktur, maka aspek-aspek atau indikator yang menjadi garis besar dalam penelitian adalah tentang bagaimana proses konstruksi sosial terhadap perilaku perempuan pulau Bontosua dalam pengelolaan lingkungan hidup. Pada bagian dokumentasi,

5 Indrawan, Rully dan Poppy Yuniawati. 2014. Metodologi Penelitian: Kuantitatif, Kualitatif, dan Campuran untuk Managemen, Pembangunan, dan Pendidikan. Bandung: PT Refika Aditama

${ }^{6}$ Gunawan, Imam. 2014. Metode Penelitian Kualitatif: Teori dan Praktik. Jakarta: PT Bumi Aksara

7 Soehartono, Irawan. 2004. Metode Penelitian Sosial Suatu Tehnik Penelitian Bidang Kesejahteraan Sosial dan Ilmu Sosial Lainnya. Bandung: PT. Remaja Rosdakarya 
fakta dan data yang dibutuhkan dalam penelitian sebagian besar tersimpan dalam bentuk dokumentasi. Sifat utama dari data dokumentasi tidak terbatas kerena itu peneliti memiliki peluang untuk menemukan hal-hal yang pernah terjadi diwaktu silam yang mungkin saja dibutuhkan. Secara detail, bahan dokumenter terbagi beberapa macam, yaitu autobiografi, surat pribadi, buku atau catatan harian, memorial, klipping, dokumen pemerintah atau swasta, data di server dan flashdisk, dan data yang tersimpan di web site. ${ }^{8}$ Dokumen yang dimaksud dalam penelitian ini adalah segala yang memuat informasi tentang Pulau Bontosua, mulai dari kondisi lingkungan hidupnya sampai pada kondisi masyarakat pulaunya.

Tabel 1. Daftar Informan Nelayan di Desa Banabungi Selatan

\begin{tabular}{|c|c|c|c|c|}
\hline No. & Nama & Pendidikan & $\begin{array}{l}\text { Umur } \\
\text { (Tahun) }\end{array}$ & Status \\
\hline 1 & Haniah & SD & \pm 56 & $\begin{array}{l}\text { 1. Ibu Rumah Tangga } \\
\text { 2. Guru Mengaji }\end{array}$ \\
\hline 2 & Rosdiana & SD & \pm 35 & $\begin{array}{l}\text { 1. Ibu Rumah Tangga } \\
\text { 2. Punya Warung } \\
\text { 3. Usaha Cao }\end{array}$ \\
\hline 3 & Sanabiah & SD & \pm 67 & $\begin{array}{l}\text { 1. Ibu Rumah Tangga } \\
\text { 2. Penjahit }\end{array}$ \\
\hline 4 & Saribono & SD & \pm 23 & Ibu Rumah Tangga \\
\hline 5 & Bunga & SD & \pm 52 & $\begin{array}{l}\text { 1. Ibu Rumah Tangga } \\
\text { 2. Punya Warung }\end{array}$ \\
\hline 6 & Saijah & SD & \pm 70 & Ibu Rumah Tangga \\
\hline 7 & Masita & SMP & \pm 31 & $\begin{array}{l}\text { 1. Ibu Rumah Tangga } \\
\text { 2. Punya warung }\end{array}$ \\
\hline 8 & Suriani & SMP & \pm 50 & Ibu Rumah Tangga \\
\hline 9 & Sudarni & SMA & \pm 20 & Tutor Paud \\
\hline 10 & Nurlia & SMA & \pm 24 & Tutor Paud \\
\hline 11 & Nisa & SMA & \pm 16 & Siswa \\
\hline 12 & Rati & SMA & \pm 17 & Siswa \\
\hline 13 & Suriani & D2 & \pm 35 & $\begin{array}{l}\text { 1. Ibu Rumah Tangga } \\
\text { 2. Guru SD }\end{array}$ \\
\hline 14 & $\begin{array}{l}\text { Hasniawati, } \\
\text { S.Pd }\end{array}$ & S1 & \pm 28 & $\begin{array}{l}\text { 1. Ibu Rumah Tangga } \\
\text { 2. Koordinator Pengelola } \\
\text { Paud }\end{array}$ \\
\hline 15 & Hasna & - & \pm 65 & $\begin{array}{l}\text { 1. Ibu Rumah Tangga } \\
\text { 2. Punya Warung }\end{array}$ \\
\hline
\end{tabular}

${ }^{8}$ Noor, Juliansyah. 2011. Metode Penelitian: Skripsi, Tesis, Disertasi dan Karya Ilmiah. Jakarta: Kencana 


\begin{tabular}{|l|l|c|c|l|}
\hline 16 & St Ramlah & - & \pm 45 & $\begin{array}{l}\text { 1. Ibu Rumah Tangga } \\
\text { 2. Kordinator Ibu PKK }\end{array}$ \\
\hline 17 & Rudi & S1 & \pm 26 & \multicolumn{1}{|c|}{ Staf Desa } \\
\hline 18 & Ahmad & SD & \pm 60 & $\begin{array}{l}\text { 1. Kepala Rumah Tangga } \\
\text { 2. Nelayan } \\
\text { 3. Guru Mengaji } \\
\text { 4. Tokoh Masyarakat }\end{array}$ \\
\hline 19 & Muh. Ridwan & - & \pm 46 & $\begin{array}{l}\text { 1. Kepala Rumah Tangga } \\
\text { 2. Ketua BPD }\end{array}$ \\
\hline 20 & Syamsir & SMA & \pm 30 & $\begin{array}{l}\text { 1. Kepala Rumah Tangga } \\
\text { 2. Tokoh Pemuda } \\
\text { 3. Jasa Transportasi }\end{array}$ \\
\hline
\end{tabular}

Sumber : Observasi Lapangan

\section{PEMBAHASAN RUMUSAN MASALAH PERTAMA}

\section{Kondisi Geografis Pulau Bontosua}

Pulau Bontosua merupakan salah satu pulau yang terletak di Kabupaten Pangkajene dan Kepulauan. Secara administratif, Pulau Bontosua masuk dalam wilayah Kecamatan Liukang Tuppabiring, Desa Mattiro Bone, Kabupaten Pangkajene dan Kepulauan, Sulawesi Selatan. Jarak antara Pelabuhan Paotere Makassar dengan Pulau Bontosua yaitu $\pm 26 \mathrm{Km}$. Untuk menjangkau daerah ini, dibutuhkan waktu sekitar 1-2 jam perjalanan dari pelabuhan Paotere Makassar dengan transportasi menggunakan perahu milik salah satu nelayan di Pulau Bontosua. Harga setiap perjalanan yaitu Rp. 20.000,- per orang. Sedangkan biaya operasional yang dibutuhkan setiap melakukan perjalanan sekali pulang-pergi sekitar Rp. 300.000,-. Perahu tersebut beroperasi hampir setiap hari, berangkat dari pulau Bontosua sekitar pukul 07.00 wita dan kembali dari Makassar sekitar pukul 12.00 wita dengan pertimbangan ombak laut belum terlalu tinggi pada jam tersebut.

Berdasarkan data yang diperoleh dari pemerintah setempat, luas pulau Bontosua sekitar satu kilometer persegi. Pulau Bontosua terdiri dari satu desa yaitu Desa Mattiro Bone yang terbagi atas dua dusun yaitu Dusun Utara dan Dusun Selatan. Masing-masing dusun terdiri dari tiga rukun tetangga (RT). Struktur pulau ini adalah pasir, hampir tidak ditemukan tanah. Maka dari itu, hanya beberapa masyarakatyang bisa menanam tumbuh-tumbuhan termasuk sayuran disekitar pemukimannya. Padahal jika dipikirkan, dengan memanfaatkan lahan kosong disekitar rumah dalam hal ini menanam sayursayuran serta buah-buahan dapat meminimalisir pengeluaran. Namun dikarenakan struktur dataran pulau sebagian besar adalah pasir mengakibatkan sulitnya tanaman tumbuh dilahan tersebut. Meskipun luas pulau Bontosua terhitung kecil yaitu hanya sekitar satu kilometer persegi, 
namun jumlah penduduknya luamayan banyak yaitu sekitar 1.160 jiwa. Berdasarkan jumlah penduduk pulau Bontosua, tak heran jika pulau tersebut terlihat padat karena dipenuhi oleh bangunan rumah-rumah penduduk.

\section{Karakteristik Sosio-Kultural Masyarakat Pulau Bontosua}

Masyarakat yang bermukim di pulau Bontosua pada umumnya berasal dari etnis Bugis-Makassar. Bahasa yang digunakan oleh masyarakat di pulau Bontosua mayoritas bahasa Makassar. Menurut penuturan salah satu penduduk di pulau Bontosua bahwa tidak ada yang mengetahui pasti siapa yang pertama kali mendiami pulau Bontosua, belum ada yang mutlak perihal sejarah masyarakat pulau Bontosua. Masyarakat nelayan di Pulau Bontosua sejak dulu memiliki nilai dan norma yang hingga saat ini sebahagian besar masih kuat dipertahankan oleh warganya. Norma sosial dapat didefinisikan aturan yang dilengkapi dengan sanksi yang merupakan patokan perilaku yang mendorong dan mengatur individu atau kelompok masyarakat tertentu. ${ }^{9}$

Norma-norma sosial biasanya terbentuk atas dasar hasil kesepakatan anggota-anggota masyarakat dan tercipta karena adanya interaksi dalam kelompok masyarakat. Pelanggaran akan norma biasanya diberikan sanksi yang telah disepakati dalam masyarakat, dimana sanksi dapat berbentuk material maupun tindakan sosial. Di sisi lain, norma merupakan penjabaran nilai-nilai secara terinci ke dalam bentuk tata aturan atau tata kelakuan yang berfungsi untuk mengatur pola tingkah laku. Masyarakat nelayan di pulau Bontosua masih memiliki nilai dan norma yang diterapkan dalam kehidupan sehari-hari. Barasanji, rebana, pa'rappo dan massalama merupakan adat leluhur yang masih diterapkan oleh masyarakat nelayan di pulau Bontosua.

Barasanji biasanya dilakukan ketika ada kapal baru yang mau pergi berlayar, biasa juga ada baranji pada saat prosesi mapacci pernikahan. Tapi kalau di acara pernikahan, sudah jarang masyarakat yang mengadakan barasanji karena barasanji memakan waktu yang lama, jadi yang biasa dilakukan ketika pernikahan adalah rebana. Selain itu, anak-anak yang bisa barasanji dan main rebana biasanya dipanggil ke desa-desa lain untuk tampil. Bahkan pernah sampai ke pangkep dan biasanya itu ada amplopnya. Pa'rappo ini sejenis kegiatan yang biasa di lakukan masyarakatsebelum melaut mencari ikan mereka meyakini bahwa kebiasaan ini bermakna meminta izin kepada sang penjaga laut untuk mencari nafka. Selain itu, dari dulu sampai sekarang setiap hari jumat menjelang magrib masyarakat akan menyalakan api yang diberi dupa.

Menurut cerita dari leluhur tradisi itu dilakukan karena setiap malam jumat malaikat akan mendekat ke rumah jika si pemilik rumah menyalakan

\footnotetext{
${ }^{9}$ Lawang, Robert M.Z. 1986. Buku Materi Pokok Pengantar Sosiologi. Jakarta: Karunika
} 
api yang diberikan dupa, aroma dari dupa itulah yang membuat para malaikat tertarik untuk mendekat. Selain ritual-ritual yang dilakukan, masyarakat nelayan pulau Bontosua juga memiliki hal-hal yang tidak boleh dilakukan karena ketika hal tersebut dilakukan dapat mengganggu keseimbangan kehidupan atau dapat mengganggu rutinitas mencari ikan. Hal tersebut biasanya disebut sebagai pantangan dalam masyarakat. Ada beberapa pantangan yang dipercayai oleh masyarakat nelayan pulau Bontosua diantaranya satu, dilarang sebut binatang yang berkaki 4 saat melaut (mencari ikan) karena akan menyebabkan rusaknya alat tangkap seperti jaring. Ke dua, dilarang bersiul karena dipercaya akan menyebabkan datangnya angin kencang saat melaut dan dapat menganggu proses pencarian ikan.

Nilai-nilai kehidupan juga masih sangat kental dilakukan oleh masyarakat nelayan di pulau Bontosua seperti nilai saling menghargai antar sesama penduduk pulau, saling menghormati antar nelayan, terbuka terhadap pendatang, nilai-nilai kejujuran, nilai kebaikan dan nilai-nilai bijak lainnya. Sikap saling menghargai masyarakat nelayan pulau Bontosua ini di samping karena masih ada hubungan kekeluargaan pada saat yang sama masyarakat di komunitas ini masih menjadikan orang tua sebagai panutan mengingat orang tua punya pengalaman hidup yang cukup serta dapat dijadikan pelajaran bagi generasi berikutnya. Ada beberapa factor seseorang di hormati dalam masyarakat nelayan pulau Bontosua antara lain kekayaan, kesholehan, kejujuran, kebaikan, keberanian, keturunan dan kepandaian namun yang paling dominan adalah kebaikan atau seberapa berpengaruhnya orang tersebut dalam masyarakat. Apapun yang dimiliki seseorang di dunia ini tapi jika ia tidak baik maka bisa saja dikucilkan dalam masyarakat. Itulah alasannya kenapa kebaikan itu harus prioritas, dan dengan baiknya seseorang maka silaturahmi dapat berjalan dengan baik dan tingkat keterterimaan di komunitas juga baik serta urusan-urasan yang lain akan menjadi mudah karena orang lain juga akan memberikan perlakuan baik dan akan tercipta ketentraman di dalam komunitas.

\section{Konstruksi Sosial Terhadap Perilaku Perempuan Dalam Pengelolaan Lingkungan Hidup}

Kajian terhadap pengelolaan lingkungan hidup berperspektif gender merupakan upaya untuk mengetahui pentingnya keterlibatan atau peran perempuan dalam pengelolaan lingkungan berdasarkan sifat-sifat yang melekat pada dirinya, baik secara seks maupun secara gender. Perspektif ekofeminisme sangat membutuhkan kosmologi baru yang memandang bahwa hidup di alam (termasuk di dalamnya manusia) dipertahankan dengan jalan saling kerjasama dan saling memberi perhatian serta saling mencintai. Hanya dengan cara tersebut memungkinkan manusia mampu merespon dan 
menerima keragaman dalam segala entitas. ${ }^{10}$ Mies dan Shiva ${ }^{11}$ menawarkan subsistensi sebagai kunci untuk menghentikan praktik dan sistem yang mengancam keberlanjutan eksistensi bumi. Keduanya meyakini bahwa "transformasi" harus bersifat material dan spiritual.

Perilaku perempuan di pulau Bontosua dalam mengelola lingkungan hidup merupakan proses eksternalisasi dari apa yang telah mereka ketahui tentang lingkungan hidup itu sendiri. Pengetahuan tersebut merupakan hasil dari pengalaman hidupnya, seperti yang dimaksud oleh Peter L Berger dalam teori konstruksi sosialnya yang akan digunakan sebagai pisau analisis dalam penelitian ini. Analisis sosiologis untuk melihat perilaku perempuan dalam mengelola lingkungan hidup harus diawali oleh pemahaman terhadap realitas sosial dan pengetahuan para perempuan tentang lingkungan hidup itu sendiri. Menurut Berger dan Luckmann ${ }^{12}$ seorang sosiolog akan mencari keterkaitan antara kondisi sosial dengan realitas dan pengetahuan. "An adequate understanding of the reality sui generis of society requires an inquiry into the manner which reality constructed" (untuk memahami realitas unik dari masyarakat secara memadai perlu diketahui bagaimana realitas itu terbentuk).

Berger dan Luckman ${ }^{13}$ mengatakan terjadi dialektika antara individu menciptakan masyarakat dan masyarakat menciptakan individu. Proses dialektika ini terjadi melalui eksternalisasi, objektivasi, dan internalisasi. Obyektivitas, internalisasi, dan eksternalisasi marupakan tiga proses konstruk sosial yang berjalan secara terus menerus. Dengan adanya dunia sosial obyektif yang membentuk individu-individu dalam arti manusia adalah produk dari masyarakatnya.

Dalam konteks penelitian ini, persepsi dan peran yang dilakukan oleh perempuan di pulau Bontosua bisa disebut sebagai realitas sosial yang terbentuk dari proses dialektika dalam masyarakat. Semisal, perempuan membuang limbah domestic di laut karena tidak memiliki pembuangan sampah khusus, kemudian dalam proses tersebut tidak ada dampak negative yang ditimbulakn jadi perilaku tersebut perlahan mengendap dan menjadi sebuah pola dalam kehidupan perempuan di pulau Bontosua. Itu terungkap dari pernyataan salah satu informan yang bernama Masita. Beliau adalah

10 Shiva, Vandana dan mies, Maria. 2005. Ecofeminism; Perspektif Gerakan Perempuan dan Lingkungan. Yogyakarta: IRE Press

11 Tong, Rosemary Putnam. 2010. Feminist Tought: Pengantar paling Komprehensif kepada Aliran Utama Pemikiran Feminis, diterjemahkan oleh Aquarini Priyatna Prabasmoro dari edisi berbahasa Inggris berjudul Feminist Tought: More Comprehensive Introduction. Yogyakarta: Jalasutra

12 Samuel, Haneman. 2012. Peter L. Berger: Sebuah Pengantar Ringkas. Depok: Kepik

13 Riyanto, Geger. 2009. Peter L Berger; Perspektif Metateori Pemikiran. Jakarta: LP3ES 
seorang ibu rumah tangga berumur sekitar 31 tahun dan memiliki warung. Berikut pernyataan beliau :

"Kalau sampah basah, saya buang di laut karena bisa dimakan oleh ikan. Kalau sampah plastic biasanya saya bakar tapi jarang sekali. Saya lebih sering buang sampah di laut. Lagian kalau ombak sudah datang sampahnya akan terbawa arus jadi pantai akan kembali bersih. (wawancara 08 april 2019)".

Sampah plastik menjadi jenis sampah yang banyak diproduksi di pulau ini tapi belum mendapatkan alternatif cara yang bisa dilakukan untuk penanganan sampah plastik tersebut. Hampir semua masyarakat pulau ini membuang sampahnya di bibir pantai dengan dalih nanti sampah tersebut akan hilang terbawa arus. Selain itu, biasanya juga dibakar. Hal yang senada juga disampaikan oleh ketua BPD, Pak Ridwan Beliau mengatakan bahwa sudah sekian kalinya beliau mengangkat isu tentang penanggulangan sampah plastik bahkan telah mengusulkan diperadakannya Bank Sampah di pulau Bontosua namun belum mendapatkan respon dari pemerintah. Karena pemerintah kurang respek dengan usulan tersebut, maka Beliau berinisiatif untuk mengajukan usulan tersebut ke PT Mars, perusahaan industry yang bekerja sama dengan Pulau Bontosua dalam budidaya karang di Pulau Bontosua. Beliau berharap agar Bank Sampah bisa diperadakan segera mungkin oleh pemerintah atau PT Mars, mengingat Bank Sampah tersebut akan sangat membantu masyarakat untuk lebih peduli terhadap kebersihan pulau serta akan berdampak pula pada lestarinya biota laut. Berikut pernyataan Beliau :

"Saya juga resah dengan sampah-sampah terutama sampah plastic yang berhamburan di bibir-bibir pantai. Selain merusak pemandangan pulau, itu juga bisa merusak biota laut. Saya sudah berapa kali meminta perhatian khusus perihal hal tersebut. Saya berulang kali meminta diperadakan bank sampah di pulau agar masyarakat juga tidak sembarangan buang sampah tapi tidak digubris. Jadi yah, kita tunggu saja dari pemerintah. (wawancara 27 Februari 2019)"

Dari hasil wawancara, peneliti dapat melihat bahwa ada beberapa faktor yang membuat masyarakat berperilaku cenderung acuh terhadap lingkungan hidup antara lain tidak tersedianya tempat pembuangan sampah atau bank sampah, tidak adanya perhatian khusus dari pemerintah, minimnya pengetahuan tentang perilaku apa saja yang dapat merusak lingkungan hidup serta dampak yang dapat mempengaruhi keberlangsungan hidup manusia saat lingkungan hidup mengalami kerusakan 
Ketika fenomena tersebut dianalisis dari sudut pandang teori konstruksi sosial oleh Peter L Berger dan Thomas Luckmann, yang berpandangan bahwa masyarakat adalah suatu fenomena dialektik dalam pengertian bahwa masyarakat adalah suatu produk manusia, yang akan selalu memberi tindak balik kepada produsernya. Masyarakat adalah suatu produk dari manusia. Masyarakat tidak memiliki bentuk lain kecuali bentukyang telah diberikan kepadanya oleh aktivitas dan kesadaran manusia. Realitas sosial tak terpisah dari manusia, sehingga dapatdipastikan bahwa manusia adalah suatu produk masyarakat. ${ }^{14}$ Melihat ketiga dimensi dialektika dalam masyarakat yaitu eksternalisasi, obyektivasi dan internalisasi kemudian dikaitkan dengan perempuan dalam pengelolaan alam di pulau Bontosua, maka dapat dijelaskan sebagai berikut :

\section{a. Proses Eksternalisasi}

Eksternalisasi adalah sebuah keharusan antropologis. Manusia, menurut pengetahuan empiric, tidak bisa dipisahkan dari keinginan untuk mengaktualisasikan dirinya dalam bentuk yang lebih konkret, aksidental. Kedirian manusia tidak bisa hanya diam dan mengendap di dalam dirinya sendiri, dalam suatu lingkup yang terbatas bahkan bisa jadi tertutup. Kedirian manusia akan selalu ingin bergerak keluar untuk mengekspresikan diridalam dunia sekelilingnya. Kedirian manusia esensisnya melakukan eksternalisasi, dan hal tersebut tentu telah hadir sejak permulaan. ${ }^{15}$

Pada proses eksternalisasi, mula-mula menjalankan sejumlah tindakan. Bila tindakan-tindakan tersebut dianggap mampu menyelesaikan persoalan mereka pada saat itu, maka tindakan tersebut akan diulang-ulang. Setelah tindakan tersebut mengalami pengulangan yang konsisten, kesadaran logis manusia secara otomatis akan mulau merumuskan serta menyimpulkan bahwa tindakan mereka merupakan sebuah fakta yang terjadi karena adanya kaidah pengaturnya. Eksternalisasi diartikan sebagai suatu sikap pencurahan kedirian menusia secara terus-menerus ke dalam dunia, baik dalam bentuk aktivitas fisis maupun dalan bentuk aktivitas mental. Artinya, setiap manusia ingin untuk melakukan hal-hal yang bisa diajdikannya sarana untuk mengaktualisasikan kediriannya.

Dalam konteks penelitian ini dapat dilihat bahwa proses eksternalisasi tertuang dalam tindakan atau peran yang dilakukan oleh perempuan di pulau Bontosua dalam mengelola lingkungan hidup. misalnya saja tindakan membuang sampah ke laut. jika di analisis dari sudut pandang Berger, tindakan tersebut telah dilakukan secara berulang-ulang dan perlahan akan

\footnotetext{
14 Berger, Peter. L. 1994. Langit Suci, Agama Sebagai Realitas Sosial. Jakarta: LP3ES ${ }^{15}$ Ibid
} 
menjadi sebuah kebiasaan. Tindakan membuang sampah di laut, dilakukan oleh para informan sejak dari masih kacil. Para perempuan di pulau Bontosua melihat sampah bertumpuk di rumahnya, kemudian orangtua mereka menyuruh membuang sampah tersebut di laut, dan dari tindakannya itu ternyata bisa menyelesaikan persoalan sampah maka diulang-ulanglah dan pada akhirnya telah mengendap dan menjadi kebiasaan dalam masyarakat. Dari hasil wawancara, peneliti mengetahui bahwa para perempuan di pulau Bontosua memuang sampah ke laut setiap pagi dan sore hari, setiap hari.

Ketika tindakan manusia dirasakan bisa menyelesaikan persolaan hidupnya, maka manusia akan mengulang-ulang tindakan tersebut dan menjadikannya sebuah kebiasaan. Sebuah kebiasaan dapat melindungi manusia dari ketidakpastian. Apabila bagi manusia tindakan yang sudah dibiasakannya itu sudah memberikannya kenyamanan, tentu ia tak harus melakukan tindakan lain untuk mwncari solusi dari masalahnya. Pada dasarnya, bagi manusia, memilih lagi atau mencoba hal baru adalah tindakan yang menakutkan, sementara rutinitas menyedihkan kenyamanan psikologis bagi manusia. 16

\section{b. Proses Obyektivasi}

Kemampuan ekspresi diri manusia mampu mengadakan obyektivasi (objectivation), artinya manusia memanifestasikan diri dalam produk-prosuk kegiatan manusia yang tersedia, baik bagi produsen-produsennya maupun bagi orang lain sebagai unsur dari dunia bersama. Obyektivasi merupakan isyarat-isyarat yang sedikit banyaknya tahan lama dari proses-proses subyektif para produsennya, sehingga memungkinkan obyektivasi tersebut dapat dipakai sampai melampaui situasi tatap-muka dimana mereka dapat dipahami secara langsung. ${ }^{16}$ Proses obyektivasi pada perempuan di pulau Bontosua berjalan pada proses pembelajaran serta pemahaman tentang pengelolaan lingkungan hidup. Proses pembelajaran dan kapasitas pemahaman para perempuan di pulau Bontosua perihal pengelolaan lingkungan hidup itu tentulah berbeda, sehingga menimbulkan perilaku yang berbeda pula atau dalam istilah Berger, eksternalisasi para perempuan pulau Bontosua tentang pengelolaan lingkungan hidup itu berbeda-beda.

Dari hasil penelusuran data, peneliti melihat bahwa adanya perbedaan proses pembelajaran serta pemahaman tentang pengelolaan lingkungan hidup oleh perempuan ibu rumah tangga biasa, perempuan yang terlibat dalam anggota Pemberdayaan Kesejahteraan Keluarga (PKK), perempuan yang berprofesi sebagai Guru, serta perempuan yang masih berstatus siswa. Perempuan ibu rumah tangga mengobyektivasi perilaku pengelolaan

\footnotetext{
16 Berger, Peter L dan Luckman, Thomas. 2013. Tafsiran Sosial Atas Kenyataan Risalah Tentang Sosiologi Pengetahuan. Jakarta: LP3ES
} 
lingkungan hidup hanya dari satu sudut pandang saja yaitu dari apa yang mereka lihat. Informan yang berstatus sebaga ibu rumah tangga biasa melihat orangtua serta orang disekelilingnya membuang sampah di laut maka mereka pun ikut membuang sampah di laut. Hal tersebut diungkapkan oleh informan yang bernama Saijah. Ibu Saijah adalah seorang ibu rumah tangga yang berumur sekitar 70 tahun. selama hidupnya, sampah yang Beliau produksi dalam rumah tangganya dibuang ke laut. Beliau mengaku bahwa hal tersebut dilakukannya berdasarkan apa yang Beliau lihat, hampir semua tetangganya juga membuang sampah ke laut.

Berbeda dengan perempuan yang berstatus sebagai siswa, mereka telah mendapatkan pengetahuan dari sekolah tentang dampak negative dari membuang sampah di laut. Hasil dari pembelajaran mereka di sekolah tentang bahaya membuang sampah di laut karena dapat merusak biota laut, perlahan membuat mereka sadar dan bertekad untuk ikut menjaga kelestarian lingkungan hidup. Namun karena kondisi, di pulau tidak memiliki tempat sampah khusus, maka mereka tak bisa berbuat banyak, hanya mampu mengurangi produksi sampah mereka secara pribadi. Para perempuan yang berstatus guru pun demikian, sejak bersekolah di perguruan tinggi, mereka mendapatkan banyak sekali pembelajaran tentang bahaya serta dampak dari membuang sampah di laut. Tidak hanya sebatas itu, perempuan yang berstatus guru ini juga merasa memiliki tanggung jawab untuk mengajarkan kepada anak didiknya serta mengajak masyarakat untuk berperilaku lebih ramah lingkungan, salah satu caranya dengan mengurangi penggunaaan produk-produk yang tidak ramah lingkungan. Hal tersebut diunkapkan oleh salah satu informan yang bernama Hasniawati, S.Pd. Beliau adalah kordinator sekolah pendidikan anak usia dini (PAUD).

Proses obyektivasi yang dialami oleh para perempuan pulau Bontosua perihal pengelolaan lingkungan hidup bisa dikatakan sebagai proses penerjemahan para perempuan terhadap tanda-tanda yang mereka inderai. Satu kasus yang sangat penting dari obyektivasi adalah signifikasi, yaitu pembuatan tanda-tanda oleh manusia. ${ }^{17}$ Sebagai contoh, tumpukan sampah yang berada di bibir pantai pulau Bontosua akan menghilang dan bibir pantai akan kembali bersih ketika ombak datang. Selain itu, tekstur wilayah daratan di pulau Bontosua yang menyerupai pasir atau bahkan mayoritas pasir bisa sebagai penanda bahwasannya hanya tanaman tertentu yang bisa tumbuh diwilayah tersebut.

\section{c. Proses Internalisasi}

Internalisasi terjadi melalui mekanisme sosialisasi. Dalam hal ini, Berger mengikuti teori Mead dari aliran Interaksionisme Simbolik. Manusia hidup dalam

${ }^{17}$ Ibid 
institusi yang mengatur posisinya dan posisi ego -ego lain. Perilaku dan tindakan manusia di tengah konteks sosialnya menunjukkan perannya. Karena itu, perilaku manusia di tengah konteks sosialnya selalu bersifat simbolik, merujuk kepada sebuah pesan atau makna. Seorang manusia yang belum mengenal kaidah-kaidah atau tatanan dari sebuah institusi bisa mempelajarinya melalui tindakan atau perilaku ego-egi lain yang sifatnya simbolik. ${ }^{18}$

Proses internalisasi yang dilalui oleh perempuan di pulau Bontosua dalam hal pengelolaan lingkungan hidup itu beragam. Maka tak heran jika persepsi serta peran atau aktivitas yang dilakukan para perempuan dalam mengelola lingkungan hidup di pulau Bontosua juga beragam. Kesadaran mereka tentulah dipengaruhi oleh kondisi sosial mereka berada. Persepsi tentang lingkungan hidup para ibu rumah tangga yang tamat sekolah dasar berbeda den gan persepsi ibu rumah tangga yang tamat sekolah menengah atas atau bahkan ibu rumah tangga yang telah sarjana. Selain itu, perbedaan persepsi tentang lingkungan hidup juga terjadi antara perempuan yang berstatus orangtua dengan perempuan yang berstatus an ak. Hal tersebut terjadi sebab proses internalisasi melaui sosialisasi yang dijalani juga berbeda.

Menurut Berger ${ }^{19}$, sosialisasi memang tidak pernah sempurna. Kebiasaan yang diwariskan kepada generasi baru selalu dapat dipertanyakan ulang karena generasi baru mungkin mulai sadar bahwa situasi kehidupan mereka berbeda dengan situasi yang dihadapi oleh generasi sebelumnya. Generasi baru tidak memiliki kesadaran kolektif seperti yang dimiliki oleh generasi sebelumnya, sehingga para generasi baru melihat bahwa persoalan mereka berbeda dengan persoalan di masa lalu. Bahkan pada generasi yang sama pun perbedaan pandangan tak bisa dielakkan, hal tersebut disebabkan oleh banyak faktor termasuk faktor pendidikan.

Misalnya saja tentang kasus membuang sampah di laut. Ibu Hasniawati yang sarjana tentulah berbeda sudut pandang dengan Ibu Sanabiah yang tidak tamat sekolah dasar. Ibu Hasniawati merasa bahwa membuang sampah di laut itu bisa mencemari laut, bisa membunuh dan merusak biota laut sedangkan Ibu Sanabiah belum mengetahui tentang dampak dari kebiasaannya membuang sampah di laut, yang beliau yakini adalah sampah bisa dibuang di laut karena di pulau Bontosua tidak tersedia tempat sampah. Tingkat pengetahuan yang lebih luas akan mampu memberi banyak pandangan atau persepsi tentang suatu hal. Berikut gambar yang dapat memberi gambaran tentang bagaimana proses konstruksi sosial terhadap perilaku perempuan dalam pengelolaan lingkungan hidup di pulau Bontosua:

\footnotetext{
${ }^{18}$ Riyanto, Geger. 2009. Peter L Berger; Perspektif Metateori Pemikiran. Jakarta: LP3ES 19 Ibid
} 


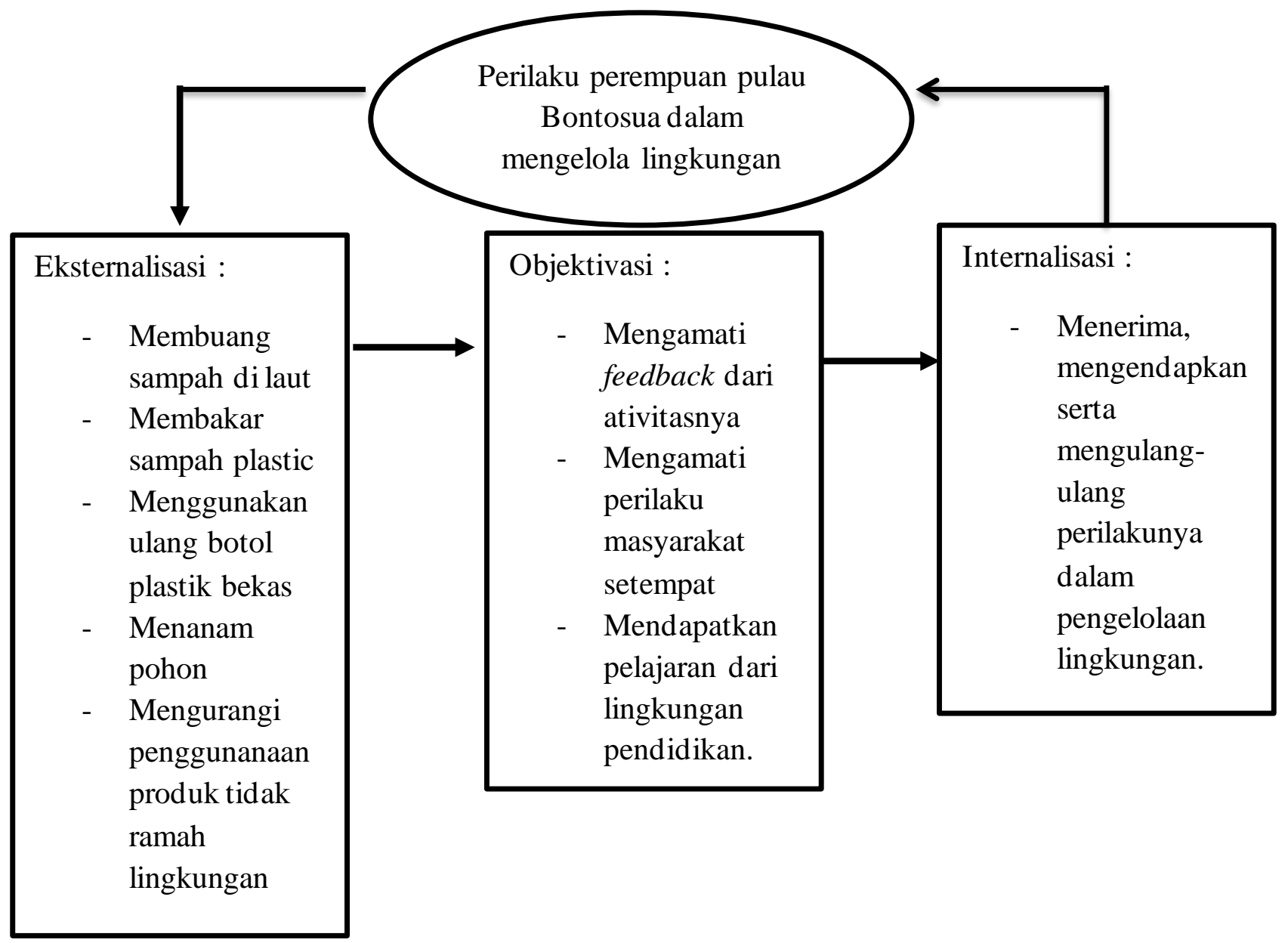

Gambar 1. Proses Konstruksi Sosial terhadap Perilaku Perempuan dalam Pengelolaaan Lingkungan Hidup

\section{PENUTUP}

Keterlibatan perempuan dalam pengelolaan lingkungan hidup terbilang penting. Sifat-sifat yang dilekatkan pada perempuan berpotensi untuk ikut serta bahkan menjadi pelopor gerakan menjaga kelestarian dan keberlangsungan sumber daya alam. Analisis konstruksi sosial melihat keterlibatan perempuan dalam pengelolaan lingkungan hidup melalui tiga dimensi yaitu pertama, eksternalisasi, dimana para perempuan mengeluarkan aktivitas terkait pengelolaan lingkungan hidup semisal me mbuang sampah di laut, membakar sampah plastic, menggunakan ulang botol plastik bekas, menanam pohon, mengurangi penggunanaan produk tidak ramah lingkungan. Kedua, obyektivasi, dimana perempuan mulai memperhatikan feedback dari aktivitas yang dilakukannya berdasarkan hasil dari interaksi sosialnya. Dan Ketiga, internalisasi, dimana perempuan mulai menerima, mengendapkan serta mengulang-ulang perilakunya dalam pengelolaan lingkungan hidup. Dari analisis sosiologis tersebut, terlihat bahwa perilaku perempuan dalam 
pengelolaan lingkungan di pulau Bontosua masih sangat minim dikarenakan proses konstruksi sosialnya yang memang kurang memperhatikan isu-isu lingkungan.

Menjaga kelestarian serta keberlangsungan sumber daya alam tentulah membutuhkan kerjasama dalam masyarakat. Instansi Pemerintah Terkait semestinya mampu mengoptimalkan regulasi yang telah dibentuk dalam kebijakan pemerintah perihal pengelolaan lingkungan serta lebih aktif dalam menindaklanjuti kebutuhan masyarakat perihal bank sampah. Instansi Pemeritah Setempat lebih memperhatikan perihal isu-isu lingkungan hidup, terkhusus perihal pengelolaan limbah plastik. Masyarakat Pulau Bontosua meminimalisir penggunanaan produk-produk tidak ramah lingkungan terutama yang terbuat dari bahan plastic sehingga mampu mengurangi pembuangan sampah plastik ke laut.

\section{DAFTAR PUSTAKA}

Astuti, Tri Marhaeni Pudji. 2012. Ekofeminisme Dan Peran Perempuan Dalam Lingkungan. Indonesian Journal of Conservation Vol. 1 No. 1 - Juni 2012.

Berger, Peter L dan Luckman, Thomas. 2013. Tafsiran Sosial Atas Kenyataan Risalah Tentang Sosiologi Pengetahuan. Jakarta: LP3ES.

Berger, Peter. L. 1994. Langit Suci, Agama Sebagai Realitas Sosial. Jakarta: LP3ES.

Bookchin, Murray. 2018. Ekologi dan Anarkisme: Kumpulan Esai, diterjemahkan oleh Bima Satria Putra. Yogyakarta: Pustaka Catut.

Gunawan, Imam. 2014. Metode Penelitian Kualitatif: Teori dan Praktik. Jakarta: PT Bumi Aksara.

Harari, Youval Noah. 2017. Sapiens, Riwayat Singkat Umat Manusia. Diterjemahkan oleh Damari Tyas Wulandari Palar dari edisi berbahasa Inggris berjudul Sapiens, 2014. Jakarta: Kepustakaan Populer Gramedia.

Indrawan, Rully dan Poppy Yuniawati. 2014. Metodologi Penelitian: Kuantitatif, Kualitatif, dan Campuran untuk Managemen, Pembangunan, dan Pendidikan. Bandung: PT Refika Aditama.

Lawang, Robert M.Z. 1986. Buku Materi Pokok Pengantar Sosiologi. Jakarta: Karunika.

Noor, Juliansyah. 2011. Metode Penelitian: Skripsi, Tesis, Disertasi dan Karya Ilmiah. Jakarta: Kencana.

Samuel, Haneman. 2012. Peter L. Berger: Sebuah Pengantar Ringkas. Depok:

Kepik.

Soehartono, Irawan. 2004. Metode Penelitian Sosial Suatu Tehnik Penelitian Bidang Kesejahteraan Sosial dan Ilmu Sosial Lainnya. Bandung: PT. Remaja Rosdakarya.

Ritzer, George. 2012. Teori Sosiologi, dari sosiologi klasik sampai perkembangan terakhir postmodern (edisi kedelapan). Yogyakarta: Pustaka Pelajar.

Riyanto, Geger. 2009. Peter L Berger; Perspektif Metateori Pemikiran. Jakarta: LP3ES. 
Shiva, Vandana dan mies, Maria. 2005. Ecofeminism; Perspektif Gerakan Perempuan dan Lingkungan. Yogyakarta: IRE Press.

Susilo, Rachmad K. Dwi. 2012. Sosiologi Lingkungan. Jakarta: Rajawali Pers.

Tong, Rosemary Putnam. 2010. Feminist Tought: Pengantar paling Komprehensif kepada Aliran Utama Pemikiran Feminis, diterjemahkan oleh Aquarini Priyatna Prabasmoro dari edisi berbahasa Inggris berjudul Feminist Tought: More Comprehensive Introduction. Yogyakarta: Jalasutra. 